\title{
Squamous cell carcinoma in plantar ulcers in leprosy. A case control study
}

\author{
J. H. RICHARDUS \& T. C. SMITH \\ McKean Rehabilitation Centre, PO Box 53, Chiang Mai 50000, \\ Thailand
}

\section{Accepted for publication 12 February 1993}

\begin{abstract}
Summary The objective of this case-control study was to identify factors associated with the development of squamous cell carcinoma (SCC) in plantar ulcers of leprosy patients. We examined 2 matched groups consisting of leprosy patients with and without SCC in a plantar ulcer.

No correlations were found between the development of SCC and race, profession, place of origin, duration of leprosy, the type and duration of leprosy chemotherapy, presence of bone involvement and type of ulcer care treatment given. The only statistically valid finding was that the duration of the ulcer was significantly lower in the group with malignant change. In this group there was an apparently higher use of pesticides, the difference being not of statistical significance.

It is concluded that factors other than ulcer duration need to be looked for, in order to identify factors influencing malignant change in plantar ulcers of leprosy patients.
\end{abstract}

\section{Introduction}

Squamous cell carcinoma (SCC) has been described as a complication of chronic, usually plantar, ulcers in leprosy patients. Recently we reviewed 38 consecutive cases of SCC in ulcers of leprosy patients presenting at the McKean Rehabilitation Centre in Northern Thailand for ulcer care. ${ }^{1}$ It was found that the incidence rate of SCC in the group at risk (leprosy patients with disability grading 1 and 2$)^{2}$ was $0 \cdot 79: 1000$ per year. The age group most commonly involved was that of 60 to 69 years and the classification specific incidence rate was highest among BT patients (2.02:1000 per year).

SCC in leprosy patients has been reported from various countries around the world. Most articles concern individual case reports. The incidence rates found in the Northern Thailand study appear to be higher than those found in, for example, India, a country with a large leprosy population. During the past 30 years only relatively small numbers of cases have been reported from India, ${ }^{3,4}$ and not many epidemiological details are available. This impression of low incidence was confirmed when a postal survey was done among 27 centres in India belonging to The Leprosy Mission (unpublished data). It was 
estimated that the incidence rate of SCC was at least a factor 10 less than found in the Northern Thailand study.

The objective of this study was to identify factors that were possibly associated with the development of SCC in plantar ulcers of leprosy patients. The method used was a casecontrol study.

\section{Methods}

The selected 'cases' were leprosy patients admitted to the McKean Rehabilitation Centre (Chiang Mai, Northern Thailand) between 1985 and 1991 and diagnosed with SCC in plantar ulcers. Those patients who were still alive in 1991 (so that additional information could be obtained from them personally), from whom sufficient data was available and for whom suitable 'controls' could be found were included in the study.

'Controls' were selected from leprosy patients with plantar ulcers but without (a history of) SCC, who during the same period presented at the Centre or one of the associated out-patient clinics. The 'controls' were matched for age-group (10-year groupings, 20-29, etc.), sex and leprosy classification.

Information obtained included general personal data, leprosy history and therapy, duration of ulcer(s) and evidence of bone involvement (osteo-myelitis). Special attention was given to the type of ulcer treatment received, in particular whether herbal or traditional medications were used. A final question concerned the use of pesticides and other chemicals in farming work.

The objective was to have 3 'control' patients for each case of SCC.

\section{Results}

The 'case' group of patients with SCC consisted of 17 individuals; 6 females (35\%) and 11 males $(65 \%)$. The average age was $60 \pm 10$ years. Included in the 'control' group were 50 patients; 17 females and 33 males. The average age was $61 \pm 10$ years. Distribution of the leprosy classification for both groups was as follows: BT: $53 \%$, BL: $29 \%$ and LL: $18 \%$. All but 5 patients were ethnic Thai. The remaining 5, all in the 'control' group, were from 5 different ethnic backgrounds common in Northern Thailand. The large majority of patients were farmers or involved in farming work. All patients in both groups showed evidence of bone involvement and (previous) osteomyelitis. History of other diseases gave no additional information.

A summary of the main results is given in Table 1. Comparing the 2 groups, it appears that there are no significant differences $(p>0.05)$ between the place of origin (leprosy colony versus independent living), the average duration of leprosy, the type and duration of leprosy chemotherapy and the use of herbal or traditional medicine as opposed to conventional ulcer treatment. Between the 2 groups, there is a significant difference $(p<0.05)$ in the duration of the ulcers. The average duration in the 'control' group is $26 \pm 12$ years. In the 'case' group, this duration is $15 \pm 11$ years. There is also an apparent, but not significant $(p=0.06)$ difference in the use of pesticides in farming work. 
Table 1. Summary of the main results from the case-control study of squamous cell carcinoma (SCC) in plantar ulcers of leprosy patients

\begin{tabular}{|c|c|c|}
\hline & $\begin{array}{c}\text { 'Case' group } \\
\text { (with SCC) } \\
(n=17)\end{array}$ & $\begin{array}{c}\text { 'Control' group } \\
(n=50)\end{array}$ \\
\hline From leprosy colony or village & $12(71 \%)$ & $37(74 \%)$ \\
\hline Average duration of leprosy & $36 \pm 8$ years & $35 \pm 11$ years \\
\hline \multicolumn{3}{|l|}{ Leprosy chemotherapy: } \\
\hline * Dapsone monotherapy & $17(100 \%)$ & $48(94 \%)$ \\
\hline${ }^{*}$ Multidrug therapy (MB and PB) & $3(18 \%)$ & $15(30 \%)$ \\
\hline Duration leprosy chemotherapy & $19 \pm 12$ years & $18 \pm 11$ years \\
\hline Duration of ulcer(s) & $15 \pm 11$ years & $26 \pm 12$ years \\
\hline Use of herbal/traditional medicine in ulcer treatment & $1(\overline{7} \%)^{*}$ & $4(\overline{8} \%)$ \\
\hline Use of pesticides or chemicals in farming work & $4(29 \%)^{*}$ & $4(8 \%)$ \\
\hline
\end{tabular}

* In 3 cases no answer obtained.

\section{Discussion}

Squamous cell carcinoma is known to be an occasional complication of long-standing ulcerative conditions such as venereal granulomas, syphilis, lupus vulgaris, lupus erythematosus, chronic ulcers, osteomyelitis sinuses, old burn scars and hidradenitis suppurativa. A number of environmental carcinogens acting on the skin have been identified, including sunlight, ionizing radiation, (medicinal) arsenic and chemical agents, especially those derived from coal (tar) and mineral oil. ${ }^{5}$ It is assumed that scar tissue in particular is abnormally susceptible to the effects of these agents.

In this case-control study no associations between the development of SCC and factors concerning race, profession, place of origin, duration of leprosy, type and duration of leprosy chemotherapy, presence of bone involvement and type of ulcer care treatment were found. The only significant difference between the 2 groups was the duration of the ulcer. It appeared that the average duration of the ulcer in the group with SCC is shorter than the 'control' group. This, in fact, is surprising. It was previously assumed that duration of ulceration is a main factor in the development of SCC. ' From the present data it is clear that factors other than just duration of ulceration determine the event of SCC.

The possibility of pesticide use (a known risk factor for SCC in the skin) as a contributing factor to the development of SCC in plantar ulcers of leprosy patients, is suggested from this study. In Thailand pesticides are readily available and used excessively. The various chemical compounds, including known carcinogens, come under many different brand names and often in cocktails. The patients concerned in this study were not able to recall the contents of pesticides they used.

There remains the question why SCC in plantar ulcers of leprosy patients seems to occur more frequently in Northern Thailand than in other countries. Tumour registry statistics in 1989 of the province Chiang Mai in Northern Thailand shows that skin cancer (all types) comes last in the list of the 10 leading sites of cancer. ${ }^{6}$ The age standardized rate (ASR) is $0.047 / 1000$ in males and $0.054 / 1000$ in females. Of all skin cancers at any site on the skin, $40 \%$ were due to SCC. The incidence rate of SCC in chronic ulcers of leprosy patients from the same geographical area was $0 \cdot 79 / 1000$, a factor 10 higher. The incidence 
of non-melanocytic skin cancer (mainly consisting of SCC) in Thailand is very small compared to countries such as Australia where this group is the most common type of cancer diagnosed $\left(95,000\right.$ new cases estimated per year) ${ }^{7}$ This is obviously related to excess sun exposure on light-skinned Caucasians. Sun exposure as a cause of skin cancer is very rare in the darker coloured Thai population. Considering this, there is no reason to assume that Thai are genetically more susceptible to SCC on their skin than are, for example, Caucasians.

It can therefore be concluded that further research is needed to identify the factors that influence malignant change in plantar ulcer of leprosy patients.

\section{Acknowledgments}

We thank Dr W. C. S. Smith, director for S.E. Asia of The Leprosy Mission International, for his many helpful suggestions and comments concerning this study.

\section{References}

1 Richards JH, Smith TC. Squamous cell carcinoma in chronic ulcers in leprosy: a review of 38 consecutive cases. Lepr Rev, 1991; 62: 381-8.

2 WHO Expert Committee on Leprosy. Sixth report. Technical Report Series, No. 768. WHO: Geneva, 1988.

3 Srinivasan H, Desikan KV. Cauliflower growths in neuropathic plantar ulcers in leprosy. J Bone Joint Surg, 1971; 53: 123-32.

${ }^{4}$ Sane SB, Mehta JM. Malignant transformation in trophic ulcers in leprosy: a study of 12 cases. Ind J Lepr, 1988; 60: 93-9.

5 Squamous cell carcinoma of the skin. In: Textbook of Dermatology. Rook A. et al. (eds). London: Blackwell Scientific Publications, 1986: 2431-7.

6 Tumor Registry Cancer Unit. Statistical Report 1989, Volume 12. Chiang Mai: Faculty of Medicine, Chiang Mai Univesity, Thailand.

7 Armstrong BK. The epidemiology and prevention of cancer in Australia. Aust N Z J Surg, 1988; 58: $179-87$. 


\section{Carcinome à cellules squameuses des ulcères plantaires dans la lèpre. Étude controlée}

\section{J. H. Richardus et T. C. Smith}

Résumé L'objet de cette étude controlée était d'identifier les facteurs associés au développement de carcinome à cellules squameuses (SCC) dans les ulcères plantaires de lépreux. Nous avons examiné deux groupes similaires composés de lépreux avec ou sans SCC dans an ulcère plantaire.

Aucune relation n'a été observée entre le développement de SCC et la race, la profession, le lieu d'orogine, la durée de la lèpre, le type et la durée de la chimiothérapie antilépreuse, la présence d'une atteinte osseuse et le type de soins donnés à l'ulcère. Le seul résultat ayant une valeur statistique a été l'observation que la durée de l'ulcère était raccourcie de façon significative dans le groupe à évolution maligne. Dans ce groupe, l'usage de pesticides était apparemment plus élevé, mais la différence n'avait pas de signification statistique.

Nous en concluons que, pour identifier les facteurs qui influencent l'évolution maligne des ulcères plantaires des lépreux, il faut chercher ailleurs que dans la durée de l'ulcère.

\section{Carcinomas de célula escamosa (SCC) en las úlceras plantares. Un estudio de control de caso}

\section{J. H. Richardus y T. C. Smith}

Resumen El propósito de este estudio de control de caso era identificar los factores asociados con el desarrollo del carcinoma de célula escamosa (SCC) en las úlceras plantares de los pacientes leprosos. Se examinaron 2 grupos equivalentes que consistían de pacientes con y sin SCC en una úlcera plantar.

No se encontraron correlaciones entre el desarrollo de SCC y la raza, profesión, origen, duración de lepra, el tipo y duración de la quimioterapia contra la lepra, la presencia de implicación ósea, ni el tipo de tratamiento de la úlcera. El único resultado de validez estadística fue que la duración de la úlcera era significativamente menos en el grupo de cambio maligno. En este grupo, parecía que había un uso más importante de pesticidas, aunque la diferencia no era significativa.

Se concluye que hay que buscar otros factores que la duración de las úlceras para identificar factores que influyen los cambios malignos de la úlceras plantares en los pacientes leprosos. 